\title{
APLIKASI KONSEP AKUNTANSI MANAJEMEN DALAM BLUE OCEAN STRATEGY
}

\author{
Ria Sandra Alimbudiono \\ c-mail: ria à ubaya.ac.id \\ Universitas Surabaya
}

\begin{abstract}
This article aims to describe the application of management accounting in the blue ocean strategy. Bhe ocean strategy is an alternative way for success. It offers a new approach that companies have to create value innovation to satisfy customers. It does not compete in cost efficiency, but it tries to open a new demand by secing the customer's potential needs. To implement this new approach, management needs appropriate information for making decision. Management accounting tools like target costing and life-cycle costing tries to provide information for a better quality of decision making in the blue ocean strategy. Target costing will serve information for new product's pricing and finctionality and bfe-cycle costing tries to analyze profitability of new product during its life-cycle. By using this tools, the blue acean strategy can be implemented in the right track.
\end{abstract}

Keywords: ethical judgment, eamings managenent

\section{PENDAHLLUAN}

Tidak ada badan usaha yang selalu unggul. Keunggulan hanya bersifat sementara. Hal ini disebabkan karena keunggulan dapat ditiru. Tidak ada satu badan usahapun yang memiliki keunggulan yang kekal, karena jika badan usaha berinovasi dan berusaha untuk menciptakan satu keunggulan, maka dalam waktu yang tidak terlalu lama, badan usaha lain akan meniru bahkan akan menambahnya dengan value yang lain, sehingga keunggulan badan usaha akan lenyap baik secara perlahan maupun secara cepat.

Oleh karena itu, badan usaha harus selalu memperbaiki kualitas kesuksesan. Badan usaha perlu mempclajari mengenai apa yang telah diperbuat masa lampau, yang telah menghasilkan perbedaan positif dan mengulangi tindakan tersebut secara sistematis untuk menghasilkan kesuksesan yang selnnjutnya. Ada beberapa langkah strategis harus selalu dievaluasi dan diperbaiki sehingga menghasilkan strategi yang selalu mengakibatkan badan usaba berada dalam kondisi unggul.

Artikel ini berusaha memaparkan mengenai suatu strategi yang memiliki pendekatan yang berbeda dengan strategi yang seringkali digunakan oleh badan usahi untuk memenangkan persaingan. Blue ocean strategy merupakan satu pendekatan yang ditawarkan untuk dapat dimplementasikan pada badan usaha dengan cara melakukan inovasi nilai. Artinya strategi ini memberi wacana bahwa untuk memenangkan persaingan, badan usaha tidak harus selalu melakukan efisiensi sampai berdarah-darah. namun badan usaha dapat melakukan pembukaan pasar baru yang belum tersentuh pesaing. Salah satu badan usaha yang melakukan menerapkan strategi ini adalah Cinque 
Da Soleil. Perusahaan sirkus ini melakukan inovasi dengan cara memberikan suguhan sirkus yung berbeda. Sirkus tidak dilakukan dalam potongan pertunjukkan yang mengedepankan tampilan badut, hewan dan akrobatik. namun, pertunjukan yang dilakukan dalam bentuk teaterikal dengan mengangkat suatu tema cerita. Pertunjukan yang disajikan dengan menggabungkan antara tarian, gerakan akrobatik, desain yang mewah dan peralatan yang sangat eanggih ini tidak bersaing dalam low cost, karena harga pertunjukan yang tidak murah tersebut selalu dibanjiri pengunjung (Kim dan Mauborgne, 2005, Jawa Pos, 3 September 2008). PT Garuda Indonesia, melalui anak perusahaannya meluncurkan Citilink yang menawarkan penerbangan antar kota, Citilink menawarkan suatu nilai baru yaitu kecepatan bertransportasi antar kota.

Pemaparan mengenai konsep blue ocean strategy dilanjutkan dengan penjelasan secara lebih detail mengenai berbagai prinsip pemandu keberhasilan blue ocean strategy. Pada bagian terakhir akan dideskripsikan mengenai aplikasi dari beberapa konsep dalam akuntansi manajemen kontemporer dalam mendukung pelaksanaan strategi tersebut di atas.

\section{PEMBAHASAN}

Lingkungan ekonomi yang semakin kompetitif seringkali mendorong badan usaha untuk selalu mencari beragam kiat baru dalam bersaing. Salah satu cara untuk dapat memenangkan persaingan adalah dengan melakukan positioning yang jelas. Positioning pada pasar menunjukkan posisi badan usaha di pasar. Penentuan ini berkaitan pula dengan target pasar yang dituju dan strategi yang tepat bagi target pasar yang ditetapkan. $\mathrm{Hal}$ ini disebabkan olch meskipun produk yang dihasilkan sama, namun karena target pasar yang dituju berbeda, maka keunggulan yang harus ditonjolkan haras berbeda pula. Sebagai contoh, dapat dilihat perbedaan strategi dari produk sabun Lifebouy dengan sabun Dove. Key success factor kedua jenis sabun tersebut jauh berbeda.

Menurut Hansen (2005) ada 4 jenis key success factor yang dapat dikelola oleh badan usaha untuk memenangkan persaingan, yaitu cost, efisiensi, kualitas, serta inovasi. Tekanan berkelanjutan (cost and efficiency) merupakan salah satu kunci kesuksesan yang akan dicapai oleh badan usaha jika badan usaha melakukan tekanan berkelanjutan untuk mengefisienkan biaya. Efisiensi dapat dilakukan dengan menganalisis seluruh fungsi dan aktivitas dalam rangkaian value chain badan usaha. Penekanan secara berkesinambungan pada semua aktivitas yang dilaksanakan seringkali mengakibatkan badan usaha berada dalam kondisi sulit. Kualitas merupakan sesuatu hal yang dapat membawa badan usaha dalam kesuksesan.

Badan usaha yang telah memilith untuk bersaing dalam hal kualitas selalu berusaha memenuhi kebutuhan customer dengan menyediakan kualitas desain dan quality of conformance tinggi. Untuk memenuhi hal ini, badan usaha seringkali harus melakukan perbaikan berkelanjutan sampai pada tahapan zero defect. Time berbicara masalah ketepatan waktu, baik customer response time, maupun new-product development time. Inovasi berarti memberi nilai tambah, atau nilai dulu yang belum pernah ada. Badan usaha yang memilih inovasi sebagai key success factor-nya harus memiliki tim pengembangan dan penelitian dapat dipereaya. Tim R\&D selalu berusaha mencari dan menemukan nilai baru yang dianggap penting oleh customer seiring dengan perkembangan lingkungan sosial, lingkungan ekonomi dan perkembangan teknologi. 
Nilai yang pada masa yang lalu dianggap kurang penting schingga tidak temusuk dalam nilai dari produk yang ditawarkan saat itu, mungkin akan menjadi penting pada satu saat di masa mendatang. Contoh yang dapat dilihat adalah pada saat air minum kemasan pertama kali dipericenalkan pada tahun 1970-an. Pada saat itu air minum kemasan merupakan burang yang sama sekali tidak dilirik dan bahkan dilecehkan oleh masyarakat. Saat itu air minum kemnsan menawarkan nilai yang belum dibutuhkan. Saat ini, air minum kemasan merupakan suatu kebutuhan, baik dari segi kepraktisan dan kehigienisan. Duri contoh sederhana tersebut, inovast dapat digunakan sebagai salah satu kunci kesuksesan badan usaha. Bagi badan usaha yang telah memilih inovasi sebagai kunci kesuksesannya, Blue Ocean Strutegy merupakan salah satu strategi yang mendukung terwujudnya impian menuju puncak kesuksesan.

\section{Blue Ocean Strategy}

Biue Ocean Stratexy merupakan strategi yang dilakukan badan usaha dengan cara menciptakan ruang pasar tanpa pesaing dan membuat kompetisi tidak lagi relevan. Strategi ini ditandai oleh ruang pasar yang belum terjelajuhi, penciptaan permintaan dan peluang pertumbuhan yung sangat menguntungkan (Kim dan Mauborgne 2005). Meskipun dalam strategi ini inovasi memegang peranan penting, namun inovasi dalam pengertian yang tidak harus selalu " $100 \%$ belum pernah ada". Inovasi dnpat dilakukan dengan melakukan redesign produk atau dengan penambahun nilai-nilai baru maupun dengan memperluas batasan-batasan industri yang sudah ada.

Dalam hal ini kunci kesuksesan dengan sclalu menjadi pemimpin dalam efisiensi biaya bukan menjadi prioritas pertama. Hal ini disebabkan karena bersaing dalam harga seringkali mengakibatkan badan usaha dalam kondisi tidak nyaman. Karyawan merasa tertekan dengan adanya berbagai aturan untuk. menghemat konsumsi sumber daya. Kondisi kerja dengan berbagai aturan yang melingkupi ini harus dilakukan dengan komitmen dan pemahaman yang tinggi.. Tanpa komitmen dan pemahaman, bomerang akan segera mengarah kepada kelangsungan hidup badan usaha. Orang-orang inti akan meningkalkan badan usaha karena mereka yang sudah berada pada tahapan aktuahisasi diri (dalam teori tingkat kebutuhan manusia (Maslow 1987) merasa kebutuhan aktualisasi diri sering bersinggungan dengan aturan-aturan efisiensi. Karena adanya konsekuensikonsekuensi tersebut, maka strategi ini sering disebut dengan strategi samudera merah (Red ocean strategy).

Red ocean strategy diadopsi oleh badan usaha-badan usaha yang berkompetisi dalam industri yang sudah ada, sedang blue acean strategy diadopsi oleh badan usaha yang bergerak dalam penciptaan nilai. Apabila nilai yang terciptn dapat diterima oleh pasar atau bahkan sangat diminati oleh pasar, maka tidak tertutup kemungkinan badan usaha-badan usaha yang mengimplementsikan red ocean smategy akan mulai memasuki arena peperangan dan kompetisi antar badan usaha pun segera terwujud, Oleh karena itu badan usaha dengan blue ocean strategy dihadapkan pada kondisi penciptaan nilai secara berkesinambungan.

Penciptaan nilai atau inovasi nilai secara berkesinambangan merupakan pondasi dari kesuksesan dalam impleuentasi blue ocean stralegy. Inoyasi nilai memberi penekanan yang setara pada nilai dan inovasi. Nilai tunpa inovasi cenderung berfokus pada penciptaan nilai dalam skala besar, sesuatu yang meningkatkan nilai tapi tidak 
memadai untuk membuat badan usahi unggul secara menonjol di pasar. Inovasi tanpa nilai cenderung bersifat mengandalkan teknologi, pelopor pasarifuturistic dan sering membidik sesuatu yang belum siap diterima dan dikonsumsi pasar. Inovasi nilai hanya terjadi ketika badan usaha memadukan inovasi dengan utilitas (manfaat), harga dan posisi biaya (Kim dan Mouborge 2005; Hill 1988). Utilitas/manfaat disediakan dengan cara menganalisis elemen elemen yang dibutuhkan oleh customer, namun belum disediakan oleh industri, sedang harga dan posisi biaya rendah dilaksanakan dengan menghilangkan atau mengurangi faktor-faktor yang menjadi titik persaingan dalam industri

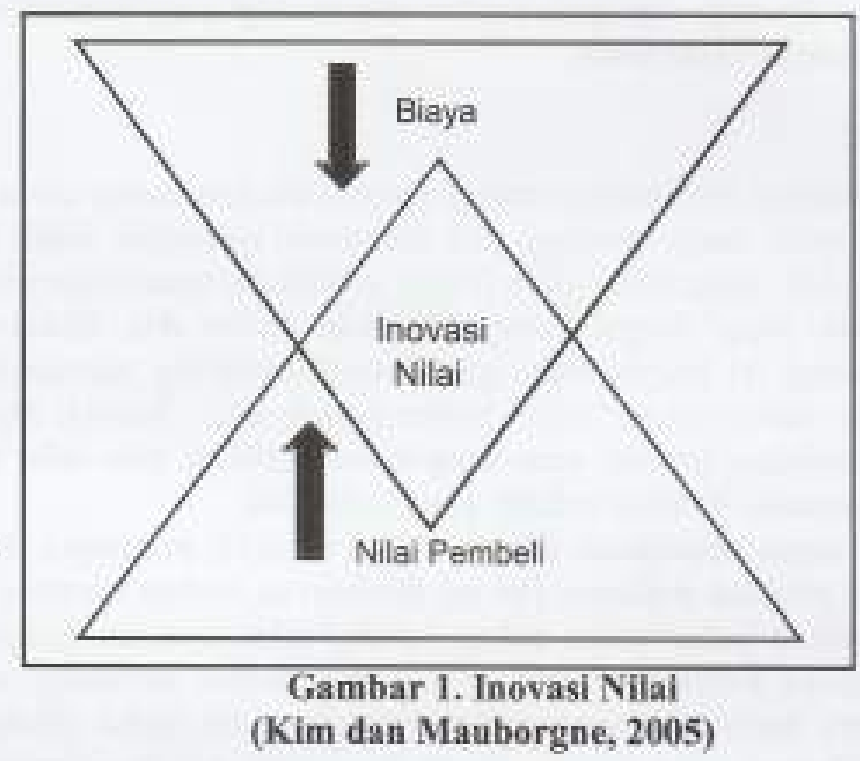

Baik red ocean strategy maupun bite ocean strategy merupakan strategi yang jika diimplementasikan dengan benar, dapat membawa badan usaha untuk berjaya di masa depan. Kedua strategi ini merupakan pilihan dan scbelum pilihan tersebut ditentukan, segala manfaat dan risiko harus dimengerti dan dipahami secara penuh

\section{Tabel 1}

Perbedaan Blue Ocean Strategy dan Red Ocean Strategy Red Ocean Strategy Blue Ocean Strutegy

\begin{tabular}{|c|c|}
\hline $\begin{array}{l}\text { Bersaing dalam ruang pasar yang sodah } \\
\text { ada }\end{array}$ & $\begin{array}{l}\text { Menciptakan ruang pasar yang belam = ada } \\
\text { pesaingoya }\end{array}$ \\
\hline Memenangi kompetisi & Menjadikan kompetisi tidak televan \\
\hline Mengeksploitasi permintaan yang adta & Menciptakan dan menangkap permaintaan bara \\
\hline $\begin{array}{l}\text { Mentilih antura milas-biaya (value cost } \\
\text { trode-off) }\end{array}$ & Merdobrak percukaran nilai-biayz \\
\hline $\begin{array}{l}\text { Memsdukan keseluruhan sistem kegiatan } \\
\text { badan usaha dengan pilihan strategis } \\
\text { antarn diferensiasi atau biaya rendah }\end{array}$ & $\begin{array}{l}\text { Memadukan keschunuhan sistem kegiatan badan } \\
\text { usaha dalam mengejar difcreasiasi dan biaya } \\
\text { rendah }\end{array}$ \\
\hline
\end{tabular}


Dari tabel 1 tersebut dapat diketahui bahwa 5 perbedaan utama dari kedua strategi di mana red ocean strategy lebih cenderung untuk memenangkan kompetisi dengan cara berhadapan, bersaing dalam ruang pasar yang sama sedang blue acean strategy lebih pada menjadikan kompetisi tidak relevan, artinya berusaha menciptakan ruang pasar baru yang belum ada pesaingnya dengan cara menciptakan permintaan baru. Oleh karena itu bagi badan usaha yang telah mengimplementasikan blue ocean strategy harus melakukan strategi ini secara berkesinambungan (sustainable), karena setiap terjadi penciptaan nilai yang unggul, maka badan usaha akan segera menghadapi kompetisi dari badan usahabadan usaha yang mengimplementusikan red ocean strategy.

Dari paparan di atas, blue acean strategy adalah strategi yang cukup ampuh dalam persaingan. Strategi blue ocean memiliki keunggulan dnlam hal inovasi. Dengan kondisi dimana daur hidup produk yang makin pendek, strategi ini merupakan salah satu alternatif dalam bersaing. Badan usaha harus lebih memfokuskan diri pada penciptaan berbagai nilai baru. Hal serupa telah dilikukan oleh banyak perusahaan sekelas Nike, IBM dan lain-lain. Perusahaan besar tersebut lebih mernilih berfokas pada penciptaan nilai dan memilih mensubkontrakan proses produksinya pada pihak lain. Dengan keunggulan ini, maka badan usaba harus memiliki tim penelitian dan pengembangan kuat, tim tersebut tidak diberi toleransi kehabisan ide kreatif dan merasa jenuh dalam berkreasi, karena kreatifitas dan inovasi merupakan tulang punggung keberhasilan implementasi strategi ini.

\section{Prinsip Pemandu Keberhasilan Blue Ocean Strategy}

Dalam menjalankan operasionalnya, badan usaha akan menghadapi risiko. Sebagaimana adanya pameo dalam teori keuangan "high risk, high return". Demikian juga dengan blue ocean strategy, strategi ini mengandung peluang yang besur, namun menghadapi risiko yang besar pula. Blue ocean strategy menawarkan peluang besar karena ketiadaan persuingan untuk berbagai produk inovatif. Badan usaha berupaya mengenalkan dan menyosialisasikan adanya nilai baru yang memiliki potensi dibutuhkan customer. Jika badan usaha berhasil, maka keuntungan besar segera diraih. Namun sebaliknya, jika pengenalan nilai kepada customer tidak berhasit, maka risiko kerugian segera menghadang. Risiko tersebut antara lain: risiko pencarian, risko perencanaan, risiko skala, risiko model bisnis, risiko organisasi dan risiko manajemen. Risiko pencarian dan risiko perencanaan merupakan akibat dari ketidakmampuan badan usaha dalam mencermati industri alternatif sebagai alat untuk mencari batasan pasar baru. Risiko skala adalah suatu risiko akibat badan usaha gagal mengumpulkan permintaan melalui pemanfaatan kesamaan yang kuat di antara non-customer, Risiko organisasi dan manajemen adalah risiko dari sebuah orgattisasi yang menerapkan strategi dimana perubahan adalah suatu hal yang rutin. Badan usaba perlu untuk mengatasi baik hambatan teknis maupun hambatan motivasional dan politis dengan membentuk suatu kepemimpinan yang sesuai.

Dengan adanya risiko tersebut di atas, maka badan usaha perlu memiliki beberapa prinsip yang harus dipahami agar strategi ini dapat menjadi kendaraan yang cocok untuk mencapai tujuan badan usaha. Ptinsip tersebut antara lain: Pertama, melakukan rekonstruksi batasan pasar dengan cara mencermati industri alternatif, rantai pembeli, 
penawaran produk dan jasa pelengkap yang telah ada di pasar. Industri alteruatif perlu diperhatikan karena inovasi biasanya dapat diperoleh dari pemikiran yang bersifat intuitif. Yang dimaksud dengan industri alternatif adalah industri yang menawarkan produk yang memiliki fungsi dan bentuk berbeda, tapi untuk memenuhi tujuan yang sàma. Rantai pembeli juga harus dicermati karena dengan pembentukan supply chain yang tepat, para pemasok dalam rangkaian supply chain akan secara bersama-sama berusaha untuk memuaskan konsumen akhir, baik. Kedua, fokus pada gambaran besar dan bukan pada angka, artinya badan usaha harus fokus pada profil strategis kompetitor dan industri untuk mengetahui potensi pasar. Ketiga, melampaui permintaan yang ada. Keempat, melakukan rangkaian strategis dengan tepat dengan memperhatikan utilitas, harga dan biaya produk dan jasa pelengkap yang ditawarkan. Artinya badan usahn harus selalu melakukan evaluasi mengenat utilitas yang dibutukkan atau yang istimewa bagi konsumen. Badan usaha juga perlu mencari informasi mengenai harga yang bisa terjangkau oleh konsumen dan mengevaluasi mengenai kemampuan harga tersebut dalam menutupi biaya produksi dan biaya operasional serta yang terakhir adalah badan asaha perlu mengidentifikasi hambatan-hambatan dalam mewujudkan bisnis tersebut. Kelima, mengatasi hambatan utama dalam organisasi dan mengintegrasikan eksekusi ke dalam strategi (Zook, 2004, Kim and Mauborgne, 2005)

\section{Aplikasi Konsep Akuntansi manajemen dalam Blue Ocean Strategy}

Konsep-konsep dalam akuntansi manajemen kontemporer menunjukkan bahwa akuntansi manajemen dapat digunakan sebagai alat penyedia informasi yang cukup handal dalam mendukung perkembangan dan kesuksesun badan usaha. Badan usaha yang telah mencapai tahapan ketiga (Kaplan, 1998) telah mulai menyadari bahwa banyak sekali konsep dalam akuntansi manajemen kontemporer seperti target costing, life-cycle costing, kaizen costing dan lain-lain yung dapat mendukung proses learning and improvement badan usaha. Proses learning and improvement harus selalu dilaksanakan oleh badan usaha dalam rangka pencapaian kesuksesan. Proses learning and improvement dapat berjalan dengan baik jika manajemen badan usaha mendapat informasi yang tepat waktu dan relevan serta akurat untuk mendukung dan mengevaluasi strategi badan usaha baik mengenai proses, produk maupun jasa pelengkapnya. Di bawah ini akan dipaparkan beberap konsep dari akuntansi manajemen yang dapat digunakan untuk mendukung keberhasilan blue ocean strategy

\section{Target Casting}

Target casting adalah suatu metode untuk menentukan cost dari produk atau jasa yang ditawarkan berdasar harga jual yang bersedia untuk dibayar oleh konsumen (Hansen, 2005). Proses awal dari target costing dimulai dari adanya market research yang dilakukan oleh departemen pemasaran untuk menentukan karakteristik dan harga dari produk yang ukan diluncurkan. Karakteristik tersebut meliputi semua spesifikasi produk beserta jasa yang menyertainya. Karakteristik ini dapat disebut sebagai nilai dari produk tersebut. Departemen pemasaran harus mampu untuk menangkap nilai-nilai yang diharapkan oleh konsumen maupun nilai-nilai yang berpotensi untuk diharapkan konsumen atau bahkan nilai-nilai yang sebenarnya dibutuhkan namun belum disadari 
oleh konsumen. Proses ini termasuk dalam langkah pertama dari target costing, yaitu market-driven costing.

Selanjutnya dalam tahapan ini juga ditentukan harga jual dari produk yang akan diluncurkan yang bersedia untuk dibayar olch konsumen. Selain itu, badan usahs juga perlu untuk menentukan profit margin yang diharapkan, mengurangkan profit margin tersebut dari harga jual, sehingga dapat diketahui nilai dari allowable cast. Allowable cast adalah biaya yang diperkirakan secara ideal dapat dicapai oleh badan usaha. Artinya biaya yang seharusnya dapat dicapai jika kapabilitas badan usaha maupun pemasok mendukung proses yang dibutuhkan.

Langkah berikutnya dari target costing adalah product-level target casting. component level target costing dan chained target casting. Dalam product-level target costing, target cost ditetapkan dengan memperhatikan kapabilitas badan usaha dan pemasok. Dengan kondisi semua kapabilitas yang dibutuhkan mendukung, maka allowable cost adalah sama dengan target cost. Component level target casting adalah tahapin di mann tim reseanch and development badan usaha berusaha untuk mewujudkan produk masa datang. Tim ini akan menentukan farget cost dari masing-masing kumponen yang dibutuhkan dan proses yang akan dilaksanakan. Berkaitan dengan hal ini, maka tim juga akan berusaha untuk membentuk supply chain yang efisien dengan pemasok. Jika pemasok juga mengaplikasikan konsep farget casting, maka chain yang efisien akan terus dilanjutkan pada pemasok produk hulu selanjutnya.

Dari proses target costing ini secara sekilas, terlihat bahwa target costing adalah konsep yang sangat mementingkan diferensiasi produk yang memiliki value dan harga yang diharapkan oleh konsumen. Harga jual dari produk yang akan diluncurkan ini dapat dimungkinkan untuk di bawah, sama atau bahkan di atas harga dari pesaing. Hal ini sejalan dengan yang ditulis oleh Kaplan and Cooper $(1998: 224)$. ............... If competitive product have higher functionality and quality; the target selling price will have to be lower than competitor. If functionality and quality are higher, selling price can either be equal to competitors' prices or above these prices.... H.

Dari pernyataan di atas dapat terlihat dengan jelas bahwa nilai yang ditawarkan oleh badan usaha merupakan komponen yang vital untuk menentukan harga jual. $\mathrm{Hal}$ ini sejalan dengan bive ocean strategy yang menyatakan bahwa badan usaha perlu untuk melakukan inovasi nilai. Dengin melakukan inovasi nilai, maka badan usaha dapat melakukan upaya bersamaan dalam mengejar diferensiasi dan biaya rendah. Pernyataan tersebut tampak pada gambar 1.

Inti dari aplikast target costing pada bive ocean strategy adalah pada tahapan market-driven costing ini, karena dalam tahapan ini badan usaha betul-betul harus dapat mengungkapkan nilai yang diharapkan oleh konsumen dan mewujudkannya dalam bentuk produk baru. Dengan bahasa kunlitas, dapat dikatakan bahwa badan usaha harus mampu untuk memiliki quality of design yang excellent.

Untuk mendapatkan excellency tersebut, dalam badan usaha yang menerapkan blue acean strategy dilakukan suatu kerangka kerja analitis yang dikenal dengan nama kanvas strategi. Kanvas strategi memiliki dua fungsi. Pertama, merangkum situssi terkini dalam ruang pasar yang sudah dikenal. Hal ini berguna untuk memahami kondisi kompetisi, faktor-faktor yang sedang dijadikan ajang kompetisi dan memahami nilai yang saat ini didapat oleh konsumen. Informasi yang diperoleh pada tahapan ini adalah mengenai 
struktur dasar dari industri berdasar perspektif pasar. Sclanjutnya nilai-nilai tersebut diwujudkan dalam sebuah kurva nilai, yaitu penggambaran grafis mengenai kinerja relatif badan usaha berkenaan dengan faktor-faktor kompetisi dalam industri. Kedua, melakukan four action framework (kerangka kerja 4 langkah) yang terdiri dari Hapuskan, Kurangi, Tingkatkan dan Ciptakan.

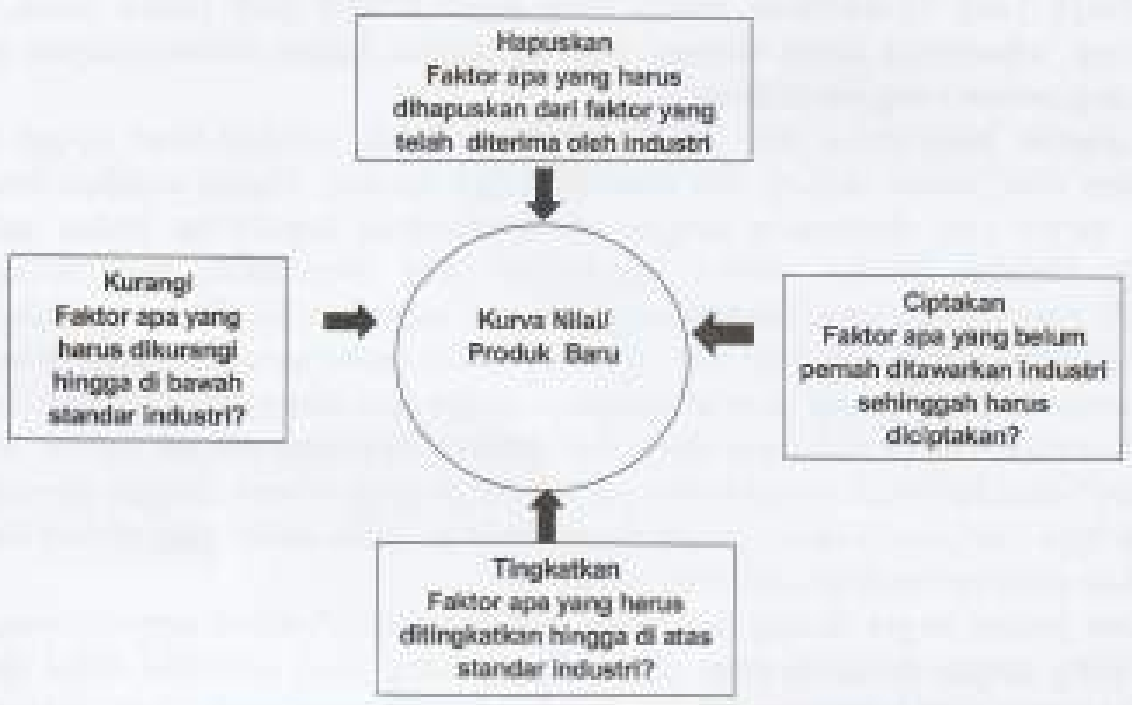

Gambar 2. Kerangka Kerja Empat Langkah

(Simber: Kim and Mauhirene, 20015)

Aktivitas hilangkan dan kurangi merupakan aktivitas yang berkaitan dengan cara pencapaian target cost yang telah ditetapkan. Pada aktivitas ini badan usaha perlu untuk mengevaluasi struktur biaya dan mengeksplorasi nilai yang sesungguhnya dibutuhkan olch konsumen. Hal ini disebabkan karena seringkali produk atau jasi badan usaha selama ini dirancang terlalu berlebihan dengan satu tujuan yaitu memenangkan persaingan. Dengan adanya aktivitas hilangkan ataupun kurangi, maka badan usaha dapat melakukan banyak sekali penghematan biaya. Tindakan menghilangkan dan menciptakan juga mendorong badan usaha untuk melangkah melampaui praktik maksimalisasi nilai dari faktor-faktor yang ada dalam kompetisi. Tindakan ini juga mendorong badan usaha uatuk mengubah faktor-faktor dan aturan yang ada dalam kompetisi/persaingan sehingga persaingan menjadi tidak lagi relevan.

Kerangka kerja empat langkah ini dapat dilaksanakan baik dalam tahapan market research dalam market-driven costing maupun dalam tahapan melakukan value engineering dalam rangka pencapaian target cost. Dalum tahapan value engineering, proses menghilangkan, mengurangi, menciptakan dan meningkatkan walue harus dievaluasi oleh satu tim yang terdiri dari berbagai deparmen, antara lain tim desain, tim production and planning control, tim produksi, tim pembelian, dan bahkan untuk badan usaha yang telah mengimplementasikan supply chain, maka tim dari pemasok-pun harus ikut ambil bagian. 
Sebagai illustrasi dapat dilihat pada inovasi nilai yang telah dilakukan oleh sebuah badan usaha yang bergerak di transportasi (busway) di Amerika Serikat sekitar tahun 2001(Kim and Mauborgne,2005). NABI adalah sebuah badan usaha busway yang tidak ingin berkompetisi dalam hal harga. Oleh karena itu, NABI berusaha untuk memberi layanan yang tidak pernah ada sebelumnya, yiatu dengan membuat bus yang berbahan fiberglas. Dengan bahan fiberglass, maka bus akan menjadi lebih ringan sehingga lebih irit bahan bakar dan emisi gas buang-pun lebih sedikit. Dengan isu penyelamatan planet dari polusi, NABI berusaha meraih simpati dari masyarakat. Selain itu dengan menggunakan bahan fiberglas, bis tidak akan keropos, berkarat dan jika terjadi kecelakaan kecil yang mengakibatkan bodi bus rusak, maka penggantiannya-pun menjadi lebih mudah dan murah. Gambaran dari kanvas strategi busway NABI adalah sebagai berikut:

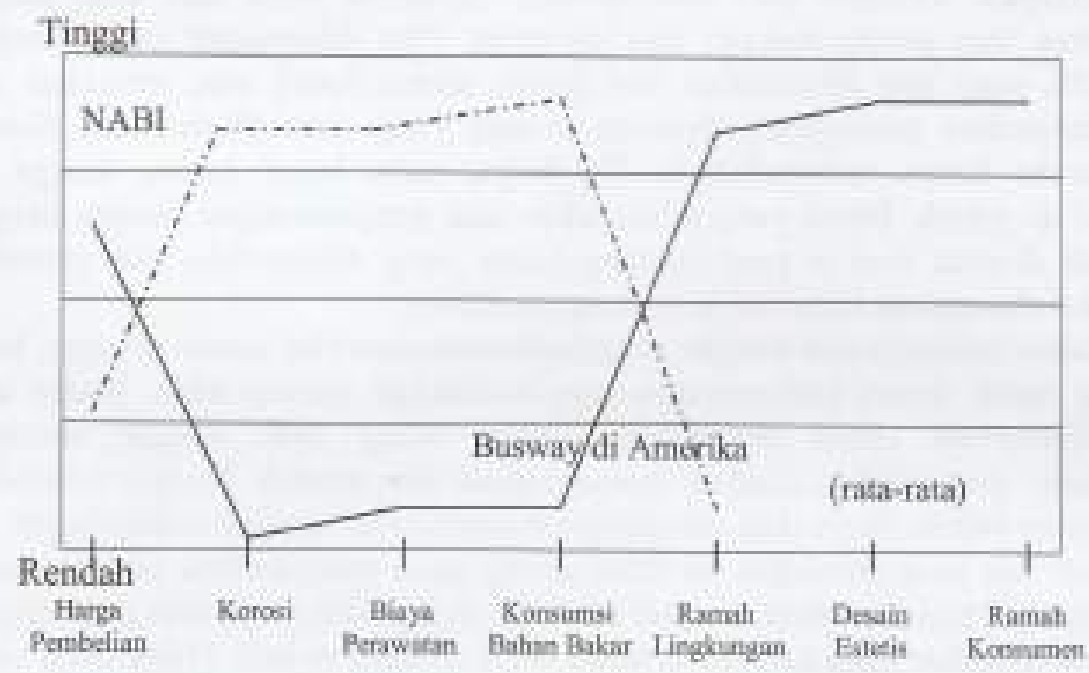

\section{Gambar 3. Kanvas Strategi Busway NABI, sekitar tahun 2001}

Dari kanvas strategi ini terlihat bahwa saat implementasi target costing, NABI tidak mengambil mengambil posisi cost Jeadership, namun dengan melakukan inovasi nilai, maka biaya perawatan dan konsumsi bahan bakar menurun sehingga secara tidak langsung mengakibatkan badin usaha melakukan penghematan biaya. Selain itu NABI menciptakan nilai-nilai baru dari sebuah industri transportasi. Nilai yang luar biasa baik bagi pemerintah kota maupun bagi penumpang bus, yaitu nilai ramah lingkungan, desain estetis dan ramah konsumen. Sehingga tidaklah suatu hal yang mengejutkan kalau NAB] segera meraih pangsa pasar terbesar dengan tingkat pertumbuhan profitabilitas yang tinggi. Dari illustrasi ini dapat terlihat bahwa penerapan konsep target costing untuk blue ocean strategy dapat dilakukan secara sinergis sehingga menghasilkan peningkatan daya saing bagi badan usaha. 


\section{Life-cycle Costing}

Life-cycle casting adalah proses perhitungan biaya dengan memasukkan semua komponen biaya yang mungkin terjadi selama hidup dari produk tersebut. Pada dasarnya, sebelum produk tersebut diluncurkan, produk tersebut telah mengkonsumsi sejumlah sumber daya, selanjutnya pada saat produk tersebut akan diluncurkan, setelah diluncurkan dan sampai dengan produk tersebut sampai ke tangan konsumen, produk tetap mengkonsumsi sumber daya. Secara singkat, dapat dikatakan bahwa suatu produk akan mengkonsumsi sumber daya sejak dari proses penelitian sumpai dengan proses after sales service, mulai dari muncul ide pembuatan produk sampai dengan produk tersebut dalam kondisi declining (Kaplan and Cooper, 1998).

Dari gambar 4 tersebut di atas, dapat terlihat bahwa sebagian besar biaya produk dikonsumsi saat produk tersebut dalam perencanaan, atau dengan kata lain, produk berada dalam tahapan research and development. Sebanyak $66 \%$ dari total biaya produk dikeluarkan saat pengembangan dan sebanyak $19 \%$ dikonsumsi pada tahapan desain awal, $10 \%$ yang lain dikeluarkan saat desain secara detail, atau seringkali saat badan usaha melakukan prototyping terhadap produk yang akun diluncurkan. Saat produksi badan usaha hanya menambahkan $5 \%$ biaya, yaitu biaya bahan, tenaga ketja dan overhead di pabrik. Biaya yang dikeluarkan saat pengembangan sampai dengan desain seringkali disebut lock-in cost. Sedang biaya yang dikeluarkan saat produk tersebut diproduksi dinamakan incurred cosa(Hongren, 2006).

Dalam hubungannya dengan pengimplementasian blue ocean strategy, badan usaha didorong untuk secura berkesinambungan melakukan inovasi nilai. Badan usaha akan selalu dimotivasi untuk melakukan desain ulang baik dengan menghilangkan, mengurangi, menciptakan maupun meningkatkan nilai produk. Dengan kondisi ini, dapat dibayangkan bahwa biaya riset dan pengembangan akan menjadi cukup besar. Tingginya biaya riset dan pengembangan ini tidak jarang akan menyurutkan niat dan minat pibak manajemen. Kondisi ini akan menjadi lebih parah lagi jika biaya riset dan pengembangan tersebut dibebankan pada periode di mana biaya tersebut terjadi. Manajemen akan merasa bahwa kinetjanya dianggap buruk saat awal peluncuran produk baru. Sehagai illustrasi dapat dilihat dari adanya bisnis taxi udara yang dilakukan oleh Lippo Group di Tangetang. Bisnis ini merupakan bisnis yang inovatif dalam rangka mengatasi kemacetan kota Jakarta. Jika dilihat dari penelitian dan investasi yang harus dilakukan pada awal bisnis ini dijalankan, maka hampir dapat dipastikan bahwa bisnis ini dianggap tidak menguntungkan. Namun, setelah tiga tahun berjalan, bisnis ini merupakan bisnis yang sangat menguntungkan, karena helikopter sebagai sarana transportasi bebas macet sangat diminati oleh para pebisnis yang menginginkan kepraktisan dan kecepatan dalum beraktifitas.

Selain masalah keengganan pihak manajemen yang berkaitan dengan penilaian kinerjanya, pembebanan biaya riset dan pengembangan tersebut juga memberi dua dampak distorsi biaya. Pertama, profitabilitas dari produk akan terlihat sangat menurun atau bahkun merugi. Hal ini akan berdampak pada proses penetapan harga, keputusan outsourcing atau bahkan penghentian produksi. Kedua, badan usaha akan gagal dalam mengevaluasi kesuksesan produk. Kegagalan ini, jika terjadi secara berulang, akan mengakibatkan badan usaha melakukan proses evaluasi strategi dan mengganti strategi 
yang dianggap terlalu costly, Kondisi ini sangat kontradiktif dengan yang diharapkan badan usaha yang menerapkan blue ocean strategy.

Oleh karena itu, sejalan dengan bive ocean strotegv, akuntansi manajemen menawarkan adanya pendekatan life-cycle casting dalam mengevaluasi kelayakan dan profitabilitas produk yang diluncurkan. Dengan life-cycle costing, profitabilitas produk tidak dianalisis secara tahunan, namun secara menyeluruh sepanjang daur hidup produk. Cara termudah yang ditawarkan Kaplan and Cooper (1998) adalah dengan menggunakan spreadsheet di muna bagian baris diìsi dengan nama produk dan bagian kolom ditsi dengan angka tahun. Setiap akhir tahun, informasi labi rugi dimasukkan dalam kolom yang tersedia. Data ini dapat dipergunakan untuk mengetahui tingkat keberhasilan setiap produk. Informasi mengenai kapan titik impas akan tercapai juga dapat diperoleh dari data tersebut. Informasi yang tidak kalah pentingnya adalah informasi mengenai siklus hidup dari produk. Hal ini disebabkan karena pada dasarnya semua produk memiliki siklus hidup. Dan badan usaha sangat perlu untuk mencermati hal ini. Jika produk telah memasuki area kematangan, maka ini adalah saat yang paling kritis bugi badan usaha untuk segera meluncurkan produk baru yang berikutnya.

\section{PENUTUP}

Ibarat kendaraan, strategi adalah sarana yang dapat membawa badas usaha mencapai tujuannya. Oleh karena itu dibutuhkan pentilihan strategi yang tepat dengan mempertimbangkan berbagai faktor baik internal maupun eksternal. Blue Ocean strategy menawarkan satu pendekatan yang berbeđa, yaitu dengan penciptaan ruang pasar yang baru. Blue ocean strategy merupakan strategi yang berusaha membawa badan usaha untuk menciptakan nilai-nilai baru yang belum terpenuhi atau bahkan belum terpikirkan oleh konsumen. Deogan demikian, badan usaha akan menawarkan sesuatu yang baru bagi konsumen.

Dalam menawarkan suatu produk atau jasa yang inovatif, terkandung peluang dian sekaligus risiko yang cukup besar. Peluang besar akan diraih, jika badan usaha dapat dengan teput menangkap nilni-nilai yang dibutuhkan oleh konsumen. Sebaliknya, risiko besar akan menghadang jika terjadi kondisi yang berkebalikan. Adanya biaya penelitian dan pengembangan yang cukup besar merupakan salah satu risiko yang dihadapi badan usaha. Oleh karena itu, salah satu konsep dalam akuntansi manajemen kontemporer, yaitu farget costing berusaha untuk membantu dalam penyediaan informasi pendukung proses inovasi nilai yang dilaksanakan dalam bize ocean strutegy. Dalam target costing, badan nsaha berusaha mencari differensiast produk pada harga yang bersedia dibayat oleh konsumen. Hal ini sejalan dengan sasaran biue ocean strategy yaitu mengejar differensiasi dan biaya rendah secara bersamaan.

Selain target costing, konsep life cycle costing juga membantu munajemen badan usaha untuk dapat mengevaluasi profitabilitas dari produk secara lebih proporsional. Dalam life-cycle costing, pembebanan biaya harus diukur selama masa hidup produk tersebut. Hal ini sangat berguna untuk mendorong badan usaha melukukan inovasi nilai. Biaya yang dikeluarkan pada masa awal atuu bahkan sebelum produk diluncurkan yang biasanya mencapai $66 \%$ dari total biaya selama masa hidup produk barus dievaluasi dan dibebankan secara proporsional. Kondisi ini perlu dilaksanakan oleh badan usaha, agar 
pihak manajemen tidak mengalami keengganan dalam melakukan inovasi nilai berkaitan dengan penurunan kinerja pada awal peluncuran produk baru

Dari paparan ini dapat terlihat adanya dukungan dari akuntansi manajemen bagi penerapan strategi badan usaha. Kondisi ini terjadi dalam semua badan usaha, karena pada dasamya keluaran dari akuntansi manajemen adalah informasi yang dibutuhkan oleh manajemen dalam melaksanakan fungsi perencanaan dan pengendalian, perhitungan biaya dan pengambilan putusan

\section{DAFTAR PUSTAKA}

Blancard, B.S., 1978, Design and Manage to Life-cycle Cost, Portland Ore., M/A Press. ., 1989, Design to Cost, New York: John Wiley \& Sons.

Castellano, Joseph F, and Saul Young, 2004, Journal of Accounting Education, Vol 21 Isuue 2, 2nd Quarter, p. 149-155

Hansen, Don R. Maryanne M. Mowen, 2005, Management Accounting, 7th edition, South-Western.

Hongren, Charles T., Srikant M. Datar and George Foster, 2006, Cost Accounting: a Managerial Emphasis, 12th edition, Pearson International Edition

Hamel, Gary dan C.K. Prahalad.1994, Competing for the Future, Boston: Harvard Business School Press

Hill, Charles W.L. 1988, Differentiation versus Low Cost or Differentiation and Low Cost, Academy of Management Review 13, July, $401-412$

Kaplan, Robert S. and Robin Cooper, 1998, Cost and Effect: Using Integrated Cost systems to Drive Profitability and Performance, Harvard Business Schol Press

Kim, W, Chan and Renee Mauborgne, 2005, Blue Ocean Strategy, Harvard Business. School Publishing Corporation

Maslow, Abraham, 1987, Motivation and Personality NY: Harper, Third Ed, NY: Addison-Wesley

Porter, Michael E, 1980, Competitive Strategy, New York : Frec Press

Robbins, Stephen P., 2000, Essentials of Organizational Behavior, Sixth Edition, Prentice-Hall, Upper-Saddle River, New Jersey

Zook, Chris,, 2004, Beyond The Core: Expand Your Market Without Abandoning Your Roots, Boston: Harvard Business School Press 
Kami Haturkan Terimakasih Kepada Para Mitra Bestari:

Wilopo (STIE Perbanas)

Imam Ghozali (Universitas Diponegoro)

Sujoko Efferin (Universitas Surabaya)

Indrawati Yuhertiana (UPN Surabaya)

Nur Fadjrih Asyik (STIESLA Surabaya) 